\title{
INDIGENOUS KNOWLEDGE ON USE OF LOCAL FODDER TREES IN MID HILLS OF WEST \\ NEPAL \\ Mohan P. Panthi*
}

\begin{abstract}
Fodder shortage (quality as well as quantity) has been found throughout mid hills of Nepal. The tree fodder is particularly important as a green, nitrogen supplement to poor quality crop residues during the dry season when feeds are scarce. The nutritional values of fodders differ according to species and season therefore farmers prefer different species for different seasons to feed their livestock. The choice or preference of fodder species by farmers reflects their traditional knowledge on nutritional values, palatability, cultivation easiness and seasonal variability of tree fodder in local environment. The paper highlights an indigenous knowledge system that relates to the quality of tree fodder used by farmers in mid hills of Nepal. In total 69 plant species have been recorded as tree fodder and out of them ten best tree fodders have been listed on the basis of preferences and priority by farmers. Information was gathered through a semi structured open questionnaire by interviewing 85 respondents of different age groups of Arghakhanchi district. Though Ficus species was the most abundant among tree fodder, Grewia optiva (locally known as 'phorso') was found the most preferable tree fodder species in the study area.
\end{abstract}

Key words: Tree fodder, folk classification, indigenous knowledge, mid hills.

\section{INTRODUCTION}

Fodder shortage has been a serious problem for livestock holders throughout mid hills of Nepal. It becomes acute during the dry period and winter when livestock is generally under fed by one-third of the required amount (Sherchan and Pradhan, 1997). Fodder trees and shrubs are used in Nepal as protein supplements in ruminant diets during the long dry period (October-May). It is estimated that $12 \%$ of the total digestible nutrients come from fodder tree and shrub (New Era, 1990). Livestock has remained as an indispensable part of the traditional agriculture system in hilly regions of Nepal (Devkota and Rerkesem, 1994). However, the productivity of livestock is very low. The major region of low productivity of the livestock is insufficient and low quality feeds and fodders (Tulachan and Neupane, 1999, Pandey et al., 1998). Livestock requires a balance diet which has sufficient energy, proteins and vitamins. Feeding with any fodder is not enough to ensure its good health and milk production. Hence, fodder trees from forests, private agriculture lands play major role to meet the deficiency of livestock feeds in hilly region. Farmers harvest tree fodder mainly from the community or private forest.

Mr. Panthi is an Associate Professor, Department of Botany, Butwal Multiple Campus, T.U, Butwal, Nepal. 
Farmer through their empirical knowledge has been practicing two local classification systems for tree fodder (Thapa et al., 1997); posilo and obano. Posilo that was perceived as an indicator of general nutrition may relate to the ability of a tree fodder to promote the supply of protein, and the other (obano) appeared to relate to digestibility of fodder in the body of cattle. The ideal multipurpose tree species should be able to fulfill the six 'Fs', basic objectives of fodder, fuel, fiber, fruit/food, forest and fertilizer (green manure) (Raghavan, 1990). The desirable agronomic characteristic of fodder tree are: ease to establishment, good competitive ability, high productivity and persistence under repeated cutting or grazing, require no fertilizer, resistant to local pests and diseases, ability of propagation, and have good nutritive value and reasonable palatability to animals (Ivory, 1990).

The main objective of the study was to find out farmer's preference of local fodder tree species, their criteria for assessing fodder species and best fodder in the mid hills of west Nepal. The specific objectives were (i) to list out all fodder trees, (ii) to record top ten best tree fodders, (iii) to understand nutritional values of the best tree fodder, and (iv) to know indigenous knowledge of farmers on classification system of fodder plants.

\section{STUDY AREA}

The district Arghakhanchi, a part of midhill of Western Nepal is located between $27^{0} 45^{\prime}-28^{0} 06^{\prime} \mathrm{N}$ latitude and $80^{\circ} 54^{\prime}-83^{\circ} 23^{\prime}$ E longitude with an area of $1193 \mathrm{~km}^{2}$. Seventy percent of population practice subsistence agriculture, but the most peasants are not self sufficient. The elevation of the district varies from $305 \mathrm{~m}$ to $2515 \mathrm{~m}$ above the sea level. The major area of the district is mid mountain and foothill, with $69.11 \%$ of area under slopes above 30 degree (ICIMOD, 1997). Of the total 119,300 ha of land in the district, $38.32 \%$ is cultivable, $23.46 \%$ of the total land area is cultivated, while forest covers $56 \%$ of the area (DADO, 2009). Community forest area per household averages 0.41 ha (FAO, 2009). Only $1.9 \%$ of farmland has year-round irrigation.

The vegetation of Arghakhanchi district basically dominated by broad leaved Schima-Castanopsis-Diospyrus mixed forest. The low land of south side of the district is covered by lower tropical Sal (Shorea robusta) forest and mixed with broad leaved forest, above this Hill Sal forest, similarly Chir-Pine (Castanopsis-Pinus) forest extended from west and Schima-Castanopsis forest extended from east meet in this area (Department of Forest, 2002). In the middle belt hill species of Sal (Shorea robusta) consists Albizia species, Anogeissus latifolia, Juglans regia, Schima wallichii, Ficus semicordata, above this belt Pinus roxburghii mixed with Castanopsis indica, Diospyrus malabarica, Rhododendron arboreum, Quercus species are associated with Maesa chisia, Berberis asiatica, Rubus ellipticus, Justica adhatoda, Zanthoxylum armatum, Woodfordia fruticosa, etc. (Panthi, 2003). 


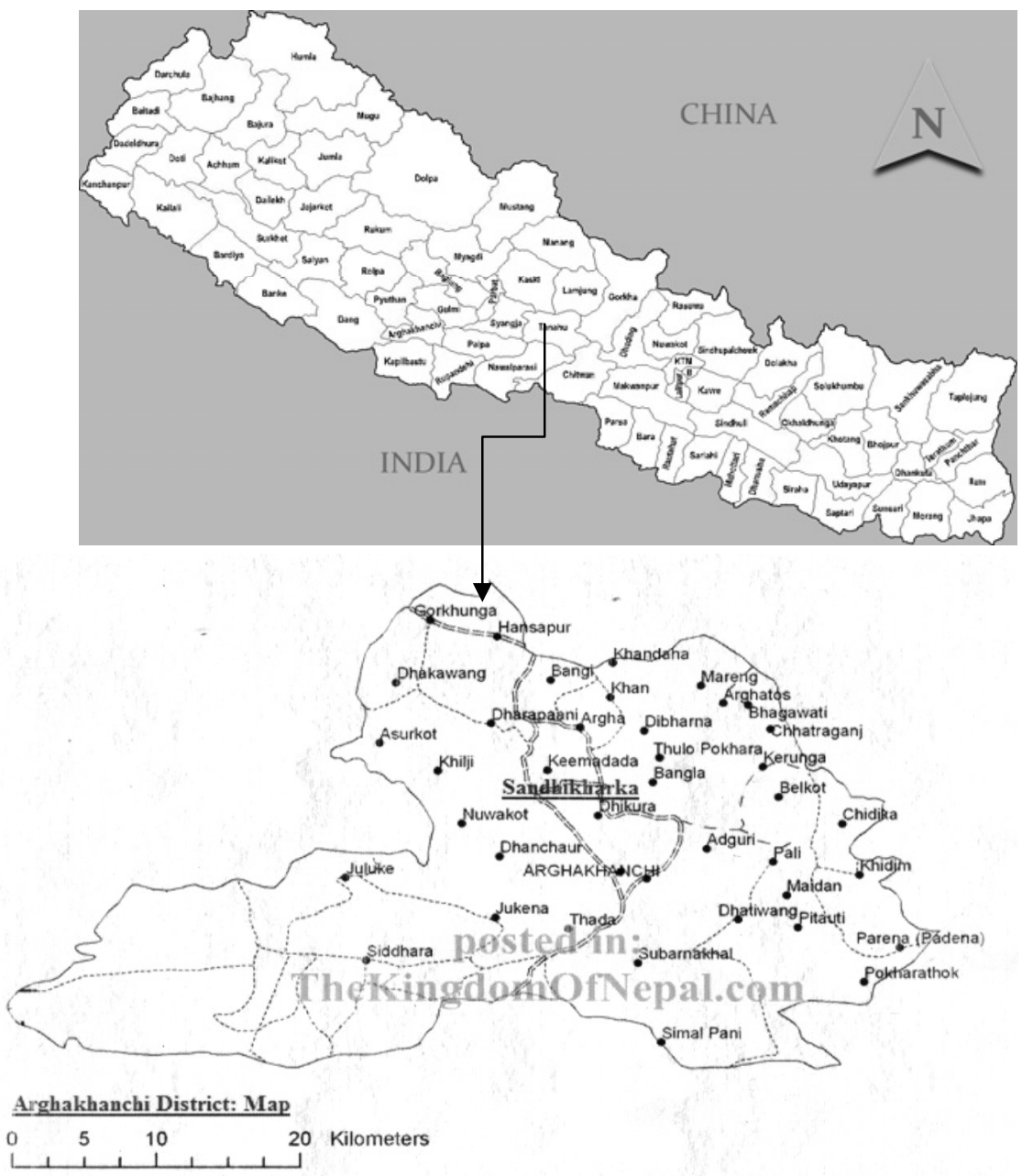

Map 1: Arghakhanchi, a midhill district of west Nepal

\section{MATERIALS AND METHODS}

Information was gathered through a semi-structured open questionnaire by interviewing 85 respondents in different age groups of different areas of Arghakhanchi district during 2003-2008. Each respondent was asked to list the fodder with their quality (fair, good and best) use in the area and rank the fodder in order of merit from 1 to 10 according to their preferences. Primary data obtained from field observation and secondary data (nutrient analysis of preferred and high ranked species) from different sources (FAO Report, 2002; Upreti and Shrestha, 2006; Dhungana et al., 2012) have been used.

\section{RESULTS}

Arghakhanchi, one of the mid hill districts of Nepal is found rich in fodder plants. It was found that all palatable plants that are browsed by livestock 
are considered as fodder. Under these criteria there were 131 species of plants under 103 genera belonging to 50 families. In total 69 trees have been recorded as tree fodder (Table 1). Out of them 24 species have been listed under best (B), 36 species under good $(\mathrm{G})$ and 9 species under fair $(\mathrm{F})$ categories. Ten best tree fodderhave been listed in Table 2 on the basis of farmers' preferences and priority. The study revealed that majority (96.47\%) of the farmers consider Grewia optiva as a highly preferred tree fodder species.

Table 1: List of tree fodder with their quality classes ( $F=$ Fair, $G=G$ Good and $\mathrm{B}=\mathrm{Best}$ ) from Arghakhanchi district.

\begin{tabular}{|c|c|c|c|c|}
\hline S.N. & Botanical Name & Local Name & Family & $\begin{array}{c}\text { Quality } \\
\text { of } \\
\text { Fodder }\end{array}$ \\
\hline 1. & Acacia catechu (L.f.) Willd. & Khayer & Leguminosae & G \\
\hline 2. & $\begin{array}{l}\text { Aesandra butyracea (Roxb.) } \\
\text { Baehni }\end{array}$ & Chiuree & Sapotaceae & $\mathrm{F}$ \\
\hline 3. & Albizia chinensis (Osbeck) Merr. & Rato/Lakka siris & Leguminosae & $\mathrm{F}$ \\
\hline 4. & Antidesma acidum Retz. & Archalo & Euphorbiaceae & G \\
\hline 5. & Artocarpus lakoocha Wall. ex Roxb. & Badahar & Moraceae & $\mathrm{B}$ \\
\hline 6. & Arundinaria falcata $\mathrm{Nees}$ & Neeyalo & Gramineae & $\mathrm{B}$ \\
\hline 7. & Bauhinia purpurea $\mathrm{L}$. & Tanki & Leguminosae & $\mathrm{B}$ \\
\hline 8. & Bauhinia variegata $\mathrm{L}$. & Koiralo & Leguminosae & $\mathrm{G}$ \\
\hline 9. & $\begin{array}{l}\text { Betula alnoides Buch.-Ham. ex } \\
\text { D. Don }\end{array}$ & Saur & Betulaceae & G \\
\hline 10. & Boehmeria rugulosa Wedd. & Geethi & Urticaceae & $\mathrm{B}$ \\
\hline 11. & $\begin{array}{l}\text { Brassaiopsis polyacantha (Wall.) } \\
\text { Banerjee }\end{array}$ & Kalo - chuletro & Araliaceae & G \\
\hline 12. & Bridelia retusa (L.) Spreng. & Gaayo & Euphorbiaceae & $\mathrm{G}$ \\
\hline 13. & Buddleja asiatica Lour. & Phurse & Loganiaceae & $\mathrm{G}$ \\
\hline 14. & Buddleja paniculata Wall. & Narayan Pati & Loganiaceae & $\mathrm{G}$ \\
\hline 15. & $\begin{array}{l}\text { Callicarpa arborea Roxb. ex } \\
\text { C.B. Clarke }\end{array}$ & Guanlo & Verbenaceae & G \\
\hline 16. & Casearia graveolens Dalzell & Kayene & Flacourtiaceae & $\mathrm{G}$ \\
\hline 17. & Castanopsis indica (Roxb.) Miquel & Katush & Fagaceae & G \\
\hline 18. & Cordia fragrantissima Kurz. & Bohari & Cordiaceae & $\mathrm{B}$ \\
\hline 19. & Dalbergia sissoo Roxb. & Sisou & Leguminosae & $\mathrm{G}$ \\
\hline 20. & $\begin{array}{l}\text { Dendrocalamus hamiltonii Nees } \\
\text { and Arn. }\end{array}$ & Tamabans & Gramineae & $\mathrm{B}$ \\
\hline 21. & $\begin{array}{l}\text { Duabanga grandiflora } \\
\text { (Roxb.exDC.)Walp. }\end{array}$ & Lampate & Lythraceae & G \\
\hline 22. & Elaeagnus infundibularis Momiy. & Madelo & Elaeagnaceae & $\mathrm{G}$ \\
\hline 23. & $\begin{array}{l}\text { Engelhardia spicata Leschen. ex } \\
\text { Blume }\end{array}$ & Mahuwa & Juglandaceae & G \\
\hline 24. & Eriobotrya elliptica Lindl. & Maya & Rosaceae & $\mathrm{F}$ \\
\hline 25. & Erythrina stricta Roxb. & Phaledo & Leguminosae & $\mathrm{B}$ \\
\hline 26. & Euonymus pendulus Wall. & & Celastraceae & G \\
\hline 27. & Ficus auriculata Lour. & Bhutuk/Newaro & Moraceae & $\mathrm{G}$ \\
\hline 28. & Ficus glaberrima Blume & Pankuri & Moraceae & $\mathrm{B}$ \\
\hline 29. & Ficus hispida L.f. & Tote, Khasreto & Moraceae & $\mathrm{G}$ \\
\hline 30. & Ficus lacor Buch.- Ham. & Seto Kavro & Moraceae & $\mathrm{B}$ \\
\hline 31. & Ficus nemoralis Wall. ex Miq. & Dudhilo & Moraceae & $\mathrm{B}$ \\
\hline
\end{tabular}




\begin{tabular}{|c|c|c|c|c|}
\hline 32. & Ficus palmata Forssk. & Bendu & Moraceae & $\mathrm{B}$ \\
\hline 33. & $\begin{array}{l}\text { Ficus semicordata Buch.-Ham. } \\
\text { ex Smith }\end{array}$ & Khaneyu & Moraceae & B \\
\hline 34. & $\begin{array}{l}\text { Ficus subincisa Buch.- Ham. ex } \\
\text { Smith }\end{array}$ & Bidilno & Moraceae & B \\
\hline 35. & Fraxinus floribunda Wall. & Lankuri & Oleaceae & $\mathrm{G}$ \\
\hline 36. & Garuga pinnata Roxb. & Dabdabe & Burseraceae & $\mathrm{B}$ \\
\hline 37. & Glochidion velutinum Wight & & Euphorbiaceae & $\mathrm{F}$ \\
\hline 38. & Grewia optiva J.R. Drumm & Phorso & Tiliaceae & $\mathrm{B}$ \\
\hline 39. & Gymnosporia falconeria Laws & Glodarim & Celastraceae & $\mathrm{F}$ \\
\hline 40. & Leucosceptrum canum Smith & Bhusure & Labiatae & $\mathrm{G}$ \\
\hline 41. & Ligustrum indicum (Lour.) Merr & Kanike & Oleaceae & G \\
\hline 42. & Litsea monopetala (Roxb.) Pers. & Kutmero & Lauraceae & $\mathrm{B}$ \\
\hline 43. & $\begin{array}{l}\text { Macaranga pustulata King ex } \\
\text { Hook. f. }\end{array}$ & Maidalo & Euphorbiaceae & $\mathrm{F}$ \\
\hline 44. & Melia azedarach L. & Bakaino & Meliaceae & $\mathrm{G}$ \\
\hline 45. & Morus australis Poir. & Kutsimal & Moraceae & $\mathrm{F}$ \\
\hline 46. & Morus serrata Roxb. & Kimbu & Moraceae & $\mathrm{G}$ \\
\hline 47. & $\begin{array}{l}\text { Myrica esculenta Buch.- Ham. } \\
\text { ex D.Don }\end{array}$ & Kaphal & Myricaceae & G \\
\hline 48. & Oroxylum indicum (L.) Kurz. & Tatelo & Bignoniaceae & $\mathrm{G}$ \\
\hline 49. & $\begin{array}{l}\text { Persea gamblei (King ex Hook. } \\
\text { f.) Koste. }\end{array}$ & Kathe Kaulo & Lauraceae & B \\
\hline 50 & $\begin{array}{l}\text { Persea odoratissima (Nees) } \\
\text { Kosterm. }\end{array}$ & Kaulo, Arjun & Lauraceae & B \\
\hline 5.1 & Premna bengalensis C.B. Clarke & Kalo Geeneri & Verbenaceae & $\mathrm{B}$ \\
\hline 52. & $\begin{array}{l}\text { Premna latifolia Roxb. Var. } \\
\text { mucronata }\end{array}$ & Seto Geeneri & Verbenaceae & B \\
\hline 53. & Prunus cerasoides D. Don & Painyu & Rosaceae & $\mathrm{G}$ \\
\hline 54. & Quercus semecarpifolia Smith & Kharsu & Fagaceae & $\mathrm{B}$ \\
\hline 55. & Quercus glauca Thunb. & Sano Phalat & Fagaceae & $\mathrm{B}$ \\
\hline 56. & $\begin{array}{l}\text { Quercus lanata Smith } \\
\text { (Q. lanuginosa } \text { D. Don) }\end{array}$ & $\begin{array}{l}\text { Sano Banjha, } \\
\text { Rayat }\end{array}$ & Fagaceae & B \\
\hline 57. & $\begin{array}{l}\text { Quercus leucotrichophora A. } \\
\text { Camus (Q. incana } \text { Roxb.) }\end{array}$ & Banjha & Fagaceae & B \\
\hline 58. & Rhus javanica L. & Bhakimlo & Anacardiaceae & $\mathrm{F}$ \\
\hline 59. & Salix babylonica L. & Baish & Salicaceae & $\mathrm{G}$ \\
\hline 60. & Saurauia napaulensis $\mathrm{C}$. & Gogon & Saurauiaceae & $\mathrm{G}$ \\
\hline 61. & $\begin{array}{l}\text { Schefflera venulosa (Weight and } \\
\text { Arn.) Harm. }\end{array}$ & Kutsimal & Araliaceae & G \\
\hline 62. & Semecarpus anacardium L.f. & Bhalayo & Anacardiaceae & $\mathrm{G}$ \\
\hline 63. & Shorea robusta Gaertn. & Sal & Dipterocarpaceae & $\mathrm{G}$ \\
\hline 64. & $\begin{array}{l}\text { Terminalia bellirica (Gaertn.) } \\
\text { Roxb. }\end{array}$ & Barro & Combretaceae & G \\
\hline 65. & Terminalia chebula Retz. & Harro & Combretaceae & G \\
\hline 66. & Toona ciliata $M$. Roem. & Tooni & Meliaceae & $\mathrm{G}$ \\
\hline 67. & Trema cannabina Lour. & Khakshi & Ulmaceae & $\mathrm{G}$ \\
\hline 68. & $\begin{array}{l}\text { Wendlandia coriacea (Wall.) } \\
\text { DC. }\end{array}$ & Tilko & Rubiaceae & G \\
\hline 69. & Xylosma controversum Clos. & Raju & Flacourtiaceae & $\mathrm{F}$ \\
\hline
\end{tabular}


Table 2: List of top ten best tree fodder species with their local name, family and percentage of preferences. (Total respondents $(n)=85$ )

\begin{tabular}{|c|l|l|l|c|}
\hline $\begin{array}{c}\text { S. } \\
\text { No. }\end{array}$ & \multicolumn{1}{|c|}{ Species } & \multicolumn{1}{|c|}{$\begin{array}{c}\text { Local } \\
\text { Name }\end{array}$} & \multicolumn{1}{|c|}{ Family } & $\begin{array}{c}\text { Preferences } \\
(\%)\end{array}$ \\
\hline 1. & Grewia optiva J. R. Drumm. & Phorso & Tiliaceae & 96.47 \\
\hline 2. & $\begin{array}{l}\text { Listea monopetala (Roxb.) } \\
\text { Pers. }\end{array}$ & Kutmero & Lauraceae & 89.41 \\
\hline 3. & $\begin{array}{l}\text { Ficus subincisa Buch.-Ham. } \\
\text { ex Smith }\end{array}$ & Bidilno & Moraceae & 85.88 \\
\hline 4. & $\begin{array}{l}\text { Dendrocalamus hamiltonii } \\
\text { Nees and Arn. }\end{array}$ & Bans & Gramineae & 84.70 \\
\hline 5. & $\begin{array}{l}\text { Ficus nemoralis Wall. ex } \\
\text { Miq. }\end{array}$ & Dudhilo & Moraceae & 82.35 \\
\hline 6. & $\begin{array}{l}\text { Ficus lacor Buch.-Ham. } \\
\text { Ham. ex Smith }\end{array}$ & Kavro & Moraceae & 82.35 \\
\hline 8. & $\begin{array}{l}\text { Artocarpus lakoocha Wall. } \\
\text { ex Roxb. }\end{array}$ & Badhar & Moraceae & 81.17 \\
\hline 9. & Quercus glauca Thunb. & Sano phalat & Fagaceae & 80.0 \\
\hline 10. & $\begin{array}{l}\text { Premna bengalensis C.B. } \\
\text { Clarke }\end{array}$ & $\begin{array}{l}\text { Kalo } \\
\text { geeneri }\end{array}$ & Verbenaceae & 80.0 \\
\hline
\end{tabular}

Out of above ten tree species, 5 best fodder trees the members of family Moraceae in which 4 species come under single genus Ficus. This result shows that species are the best and most preferable fodder among trees found in the midhill of west Nepal. In total 8 Ficus species were listed as tree fodder in the study area (Annex 1).

\section{DISCUSSION}

In Nepal, tree fodder is commonly known as daale ghans, a term being used for woody leaves and branches coming from trees, shrubs, vines and climbers. Farmers in Nepal have a considerable knowledge of fodder trees and nutritional qualities (Mahato and Subba, 1988). The nutritional values of fodders differ according to species and season of growth and, therefore, farmers prefer different species for different seasons, and animals to be fed. The traditional and experience-based choice of fodder species by farmers reflects their indigenous knowledge on nutritional values, cultivation easiness and seasonal variability of growth in local environment.

Tree fodder is particularly important as a green, nitrogen supplement to poor quality crop residues during the dry season (November to June) when feeds are scarce (Panday, 1982). Samant et al. (2007) listed 150 species of fodder representing trees, shrubs and herbs used as fodder for livestock in Indian Himalayan Region. Similarly, Dhungana et al. (2012) studied fodder trees in the Kaski district, Panday (1982) studied in Palpa district and Chapa (1994) studied from Salyan district of midhills of Nepal. Some of the species are similar with that of present finding (Table 3) and they also ranked plants on the basis of criteria similar to this paper. Present result reveled that $G$. optiva occupies the first 
position in Arghakhanchi district which coincides with finding of Chapa (1994) in Salyan, while it comes in fourth position in Palpa district. Similarly, L. monopetala is in second position which is similar to the finding of Panday (1982) in Palpa. But Artocarpus liste. lakoocha which stands in eighth position in Arghakhanchi takes first position in Palpa and Kaski districts (Table 4). Little variation in preferences may be due to the abundance of preferred trees in studied area.

The top most preferable tree fodder species Grawia. optiva, locally known as 'phorso', is grown on the edges of field terraces (bari). It has been used as multipurpose tree as leaves and young twinges are used as fodder, best quality fiber (pautta) is extracted from bark of branches and remaining core part of branches is used as easy fire catching fire wood (seetha). The main reason for considering it as the best fodder was its highly energetic, nutritious, enhancing fat production in cattle, palatability and its test. Farmer recognized it as obno as well as posilo. Out of 85 respondents 82 suggested it as highly preferred fodder tree. Similar results have been observed by Chapa (1994) in Salyan district.

The nutritive value of a fodder species is determined by its ability to provide a range of nutrients required by the animals for maintenance, growth, production and reproduction. It is related to intake, chemical composition, digestibility and the presence or absence of anti nutritional factors (Gutteridge, 1995). The nutritional value of most preferred fodder tree G. optiva is given in the table 3.

Table 3: Nutritional value of Grewia optiva

\begin{tabular}{|c|c|c|c|c|c|}
\hline Main analysis & Unit & Avg. & Mini & Max & $\mathbf{N b}$ \\
\hline Crude protein & $\% \mathrm{DM}$ & 13.3 & 10.1 & 16.4 & 2 \\
\hline Crude fiber & $\% \mathrm{DM}$ & 15.4 & 14.1 & 16.6 & 2 \\
\hline Ether extract & $\% \mathrm{DM}$ & 7.6 & 6.8 & 8.4 & 2 \\
\hline Ash & $\% \mathrm{DM}$ & 14.6 & 14.2 & 14.9 & 2 \\
\hline Gross energy & $\mathrm{MJ} / \mathrm{Kg} \mathrm{DM}$ & 17.7 & & & \\
\hline \multicolumn{6}{|l|}{ Minerals } \\
\hline Calcium & g/Kg DM & 38.8 & 35.7 & 41.8 & 2 \\
\hline Phosphorus & $\mathrm{g} / \mathrm{Kg} \mathrm{DM}$ & 2.5 & 2.5 & 2.5 & 2 \\
\hline
\end{tabular}

Source: FAO's Animal Feed Resources Information System (1991-2002) 2002.

Table 4: Most preferred fodder tree species by farmers in three (Kaski, Palpa and Salyan) midhill districts

\begin{tabular}{|l|l|l|}
\hline $\begin{array}{c}\text { Kaski district } \\
\text { (Dhungana } \text { et al. 2012) }\end{array}$ & \multicolumn{1}{|c|}{$\begin{array}{c}\text { Palpa district } \\
\text { (Panday 1982) }\end{array}$} & \multicolumn{1}{|c|}{$\begin{array}{c}\text { Salyan district (Chapa } \\
\text { 1994) }\end{array}$} \\
\hline 1. Artocarpus lakoocha & 1. Artocarpus lakoocha & 1. Grewia optiva \\
\hline 2. Ficus subincisa & 2. Listea monopetala & 2. Celtis australes \\
\hline 3. Ficus roxburghii & 3. Ficus auriculata & 3. Listea monopetala \\
\hline 4. Ficus semicordata & 4. Grewia optiva & 4. Karkale \\
\hline 5. Listea monopetala & 5. Erythrina stricta & 5. Bauhinia varigata \\
\hline 6. Ficus lacor & 6. Bauhinia varigata & 6. Ficus semicordata \\
\hline 7. Machilus odoratissima & 7. Ficus rumphii & 7. Saurauia napaulensis \\
\hline 8. Ficus glaberrima & 8. Garuga pinnata & 8. Ficus nemoralis \\
\hline 9. Brassaiopsis hainla & 9. Ficus subincisa & 9.Brassaiopsis polycantha \\
\hline 10. Ficus hispida & 10. Ficus lacor & 10. Indigofera pulchella \\
\hline
\end{tabular}




\section{Folk classification system of fodder}

Local farmers categorize the fodder on the basis of defined purposes.

(a) According to effect of fodder

(i) Obano ghans (Warm fodder) - Those palatable plant species are generally feed in moist and cold season, so that cattle will not suffer from cold e.g. F. semicordata, G. optiva, Bambusa and Dendrocalamus species, Cyperus species, Thysanolaena maxima.

(ii) Cheeso ghans (Cold fodder) -Young tender parts of palatable plant species, consumed by cattle but not preferred by farmers for cattle feeding because those fodder cause loose stool disease to livestock e.g. Litsea monopetala, Garuga pinata, Erythrina arborescens.

(iii) Posilo ghans (Milk yield increasing fodder)- Quantity of milk per cattle increases after feeding such plants e.g. Premna latifolia, F. nemoralis, A. lakoocha, G. optiva, Cynodon dactylon, Vicia angustifolia. It is said that they also increase fat in milk of lactating animals.

(iv) Beekhalo ghans (Poisonous fodder) -Some fodders are poisonous in large dose or when fed new flush of leaves and buds e.g. Lyonia ovalifolia can be fatal in young stage; Osyris wightiana and Neolistia cuipala could be fatal in large doses. Albizia chinensis, Hedychium spicatum and Prunus ceracoides may cause serious problem in some conditions.

(b) According to habit of fodder

(i) Daale ghans (Tree fodder), and (ii) Sapke ghans (Herbaciuos fodder).

\section{Conservation and management perspectives}

To increase the production of preferable fodder species, the following measures would be appropriate for the conservation and management of fodder resource of mid hills.

(1) Preparation of a comprehensive inventory/ database of fodder resources.

(2) Chemical analysis of fodder plants to identity the nutritive status.

(3) Maintain record of indigenous knowledge of fodder species for sustainable use.

(4) Development and implementation of land use plans.

(5) Promote ex-situ and in-situ conservation of fodder resource.

(6) Large scale propagation of highly preferred fodder species and dissemination of packages to local inhabitants.

(7) Identify biotechnological means to improve germination/ propagation of fodder species.

(8) Impart training on lopping, nursery, propagation and plantation techniques.

(9) Ensure people's participation and create awareness through training and use of media. 


\section{ACKNOWLEDGEMENT}

I am thankful to the respondents of the Arghakhanchi district who share their valuable indigenous knowledge in the field, without those inputs this work will not be completed.

\section{WORKS CITED}

Chapa, D.R. (1994). Fodder and desired characteristics prioritization exercise in Kapurkot, Dhanabang VDC of Salyan. Banko Janakari 4(2):143-150.

Department of Forest (2002). Forest and Vegetation Types of Nepal. TISC (Tree Improvement and Silviculture Component) document series no.105. GoN, Department of Forest, TISC, NARSAP.

Devkota, N.R. and B. Rerkesem (1994). System understanding and analysis of agriculture practices in crop livestock integrated farming system of Chitwan, Nepal. Journal of Tribhuvan University 17: 29-40.

Dhungana, S., H.P. Tripathee, L. Puri, Y.P. Timilsina and K.P. Devkota (2012). Nutritional analysis of locally preferred fodder trees of middle hills of Nepal: A Case Study from Hemja VDC, Kaski District. Nepal J. Sc. and Tech. 13(2):39-44.

DADO (2009). Annual Agriculture Development Program and Statistics. District Agriculture Development Office (DADO), Arghakhanchi.

FAO (2002). FAO's Animal Feed Resources Information System (1991- 2002) 2002. Food and Agriculture Organization (FAO).

FAO (2009). Situation Assessment and Baseline Study: Disaster Risk Management and Climate change Adaptation. Practical Action Nepal, Food and Agriculture Organization (FAO).

Gutteridge, R.C. (1995). The potential of nitrogen fixing tress in livestock production systems. A paper presented in International Workshop on Nitrogen Fixing Trees for Fodder held in Pune, India, March 20-25, 1995.

ICIMOD (1997). Districts of Nepal-Indicators of Development. International Centre for Integrated Mountain Development, Kathmandu, Nepal.

Ivory, D.A. 1990. Major characteristics, agronomic features and nutritional value of shrubs and tree fodders for farm animals. In: Devendra, C. (ed.) Shrubs and tree fodders for farm animals. Proceeding of a workshop in Denpasar, Indonesia 24-29 July 1989. Ottawa, Ontario, pp. 22-38.

Mahato, S.N. and D.B. Subba 1998. Nutritional evaluation of fodders at Pakhribas Agricultural centre, Dhankuta. In: Robinson, P.J. (ed.) Occasional Paper 2/88. Forest Research and Survey Centre, Babarmahal, Kathmandu, pp. 20-22.

New Era (1990). A study on dairy farmers in Nepal: Breeds and their potentials. New Era, Maharajganj, Kathmandu, Nepal.

Panday, K.K. (1982). Fodder Trees and Tree Fodder in Nepal. Swiss Development Cooperation and Swiss Federal Institute of Forestry Research, Switzerland. 
Pandey, S.B., R.C. Khanal and S.K. Khanal (1998). Effect of feeding ureamolasses-mineral block (UMMB) on the performance of lactating cross dairy cows. In: Technical Report. Animal Nutrition Division, NARC, Khumaltar, Lalitpur, pp. 3-10.

Panthi, M.P. (2003). Fodder plants and their indigenous management in Adguri and Narapani Village Development Committees (VDCs), West Nepal. A research report submitted to the Dean's office, Institute of Science and Technology, Tribhuvan University, Kathmandu.

Raghavan, G.V. (1990). Availability and use of shrubs and tree fodder in India. In: Devendra, C. (ed.) Shrubs and tree fodders for farm animals. Proceeding of a workshop in Denpasar, Indonesia 24-29 July 1989. Ottawa, Ontario, pp. 196-210.

Samant, S.S., M. Singh, M. Lal and S. Pant (2007). Diversity, distribution and prioritization of fodder species for conservation in Kullu District, Northwestern Himalaya, India. J. of Mountain Science 4(3): 259-274.

Sherchan, L. and S.L. Pradhan (1997). Domestic animal genetic resource management and utilization in Nepal. Department of Livestock, Kathmandu.

Thapa, B., D.H. Walker, F.L. Sinclair (1997). Indigenous knowledge of the feeding value of tree fodder. Anim. Feed Sci. and Technol. 67: 97-114.

Tulachan, P.M. and A. Neupane (1999). Livestock in mixed farming systems of Hindu Kush-Himalayas: trends and sustainability. International Center for Integrated Mountain Development (ICIMOD), Kathmandu, Nepal.

Upreti, C.R. and B.K. Shrestha (2006). Nutrient contents of feeds and fodder in Nepal. Animal Nutrition Division, NARC, Khumaltar, Lalitpur. 